\author{
Євтушевська 0.0. \\ кандидат економічних наук, доцент \\ кафедра обліку та аудиту \\ Одеська національна академія харчових технологій \\ вул. Канатна, 112, м. Одеса, Україна, 65039 \\ E-mail: olga1alex@mail.ru
}

\title{
ВДОСКОНАЛЕННЯ СИСТЕМИ ЗАБЕЗПЕЧЕННЯ НАДІЙНОСТІ ПЕРСОНАЛУ КОМЕРЦІЙНОГО БАНКУ
}

Основною метою статті $є$ розробка теоретичних та практичних рекомендацій щодо вдосконалення надійності персоналу комерційного банку. Для створення ефективної системи управління персоналом банку треба чітко визначити концепцію, принципи, політику та стратегію управління персоналом.

Ключові слова: концепція управління персоналом, принципи управління персоналом, політика управління персоналом, стратегія управління персоналом.

Постановка проблеми та їі зв'язок з важливими науковими та практичними завданнями. Численні дослідження роботи сучасних комерційних організацій дозволяють зробити узагальнений висновок - ефективність будь-якої організації, залежить від трьох важливіших умов: сприятливого ділового середовища; правильної стратегії компанії; якості і надійності людських ресурсів. На думку фахівців, перші дві умови - результат третьої - кадрового потенціалу організації. Навіть найкращі моделі, стратегії і політики терплять фіаско без компетентного здійснення.

Сьогодні надійність персоналу - основна проблема будь-якої організації, обов'язкова i дуже важлива складова частина забезпечення ефективної роботи.

Вже ні в кого не викликає сумніву той факт, що для успішного розвитку бізнесу потрібні кваліфіковані кадри. Як правило, більшість бар'єрів на шляху розвитку ринкових відносин так чи інакше пов'язані з персоналом. Наприклад: невміння працювати по-новому, невідповідність особистих цілей та цілей організації, опір нововведенням тощо.

Здійснювані в Україні економічні реформи докорінно змінюють систему взаємовідносин - між керівниками і підлеглими, між працівниками всередині господарюючих суб'єктів економіки, а також у суспільстві в цілому. Практично громадяни України входять у нову систему координат, яка визначає взаємовідносини між працедавцями і працівниками в ринковій економіці, соціальну спрямованість заходів 3 управління колективами працюючих у всіх сферах народного господарства, у тому числі в банківській системі. За цих умов постає проблема наукового обгрунтування і розробки практичних рекомендацій 3 ефективного і надійного управління персоналом комерційного банку.

Аналіз останніх публікацій 3 проблеми. Для підвищення ефективності системи управління персоналом необхідно аналізувати і враховувати специфічні умови розвитку ринкової економіки в Україні. Проблемам теорії, методології і практики управління персоналом присвятили велику кількість науко- вих праць закордонні і вітчизняні економісти: Амоша O.I., Блэк Дж., Браверман А., Дзюба С.Г., Журавльов П.В., Іванцевич Дж.М., Колпаков В.М., Лобанов А.А., Пагрушев В.Д., Паладій М.В., Поклонський Ф.Ю., Рак М.Г., Синк Д.С., Скударь Г.М., Томпсон А.А., Шекшня С.В., Шеремет А.Д., Щербакова Г.Н. та ін. А. Шеремет, Г. Щербакова, досліджуючи проблеми фінансового аналізу в банках 3 метою визначення рентабельності банку, серед інших фінансових показників використовують і показники ефективності роботи банківського персоналу. У роботах М. Паладія досліджено взаємозв'язок між досягненням бажаної продуктивності та результативності праці банківського персоналу і мотивацією праці в комерційних банках. Однак внаслідок складності й багатоаспектності цієї проблеми в сучасних умовах існують питання, розроблені не повністю.

Формулювання цілей дослідження. Основною метою статті є розробка теоретичних та практичних рекомендацій щодо вдосконалення надійності персоналу комерційного банку.

Виклад основних результатів та їх обгрунтування. Персонал - це особовий склад колективу підприємства, включаючи технічний, обслуговуючий або частина персоналу відділень по певних ознаках. Працівники підприємства - це високоякісний і цінний ресурс, яким для більшої надійності і ефективності, потрібно грамотно управляти для поліпшення якості результату і конкурентоспроможності у сучасному бізнес-середовищі [8].

Управління персоналом - скоординована система заходів щодо формування і ефективного використовування трудового потенціалу працівників в складних організаційних утвореннях ієрархічного виду. Це цілеспрямована діяльність керівного складу організації, а також керівників і фахівців підрозділів системи управління персоналом, яка включає розробку концепції і стратегії кадрової політики, принципів і методів управління персоналом [9]. Система роботи з персоналом формується у такій послідовності (Рис. 1). 


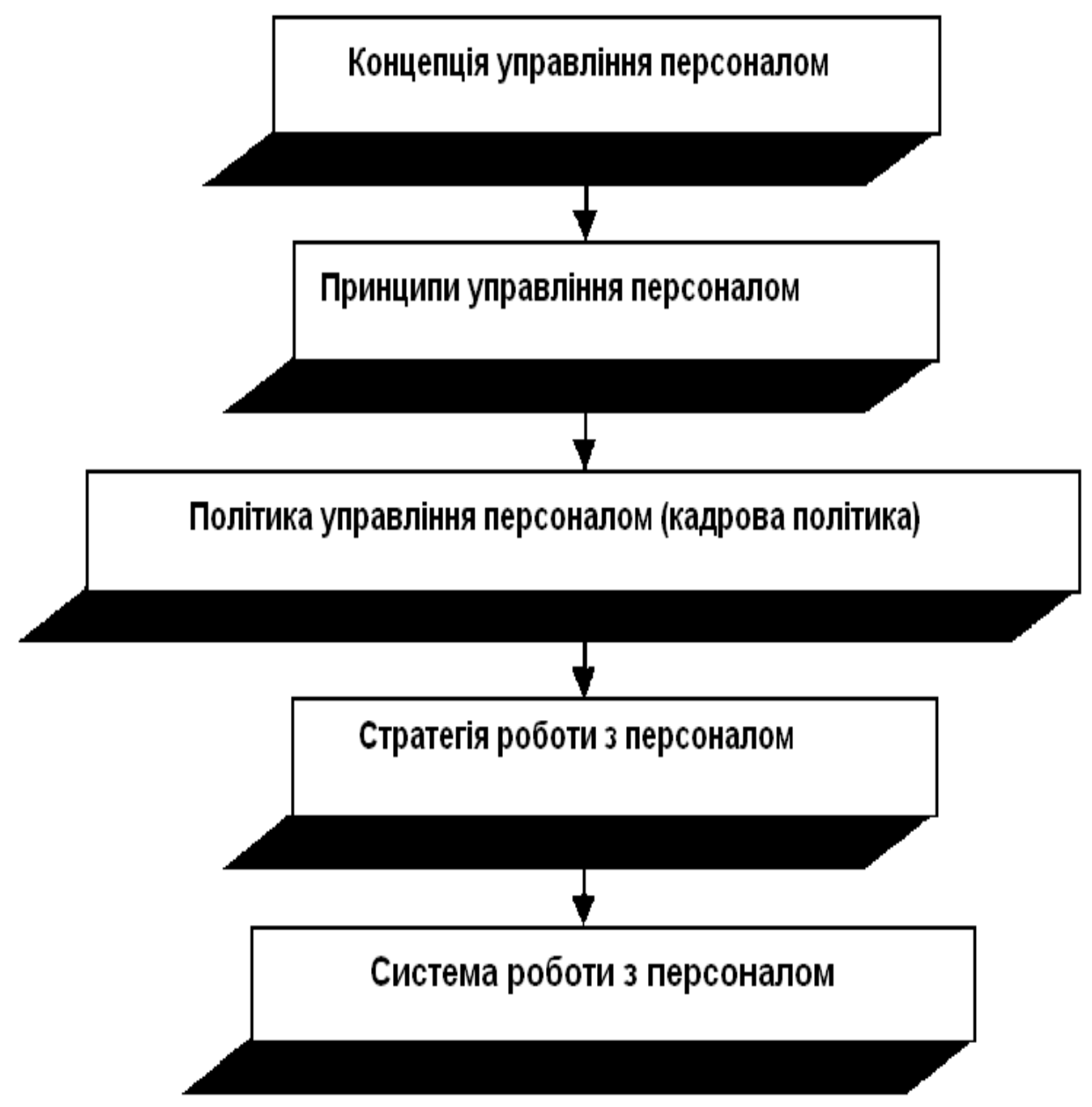

Рис. 1. Послідовність формування системи роботи з персоналом у комерційному банку

Надійність персоналу є однією 3 важливих складових будь-якого комерційного підприємства [7]. Ненадійність персоналу, яка виникає в організації, іноді приймає загрозливу форму та розрушає іiі економічну діяльність. Дану проблему слід розглядати системно у трьох напрямках: при наймі кандидатів на роботу; при профілактичних та при контролюючих заходах у роботі з персоналом.

При наймі на роботу нового співробітника повинні бути визначені:

- його особисті характеристики та потенційна можливість адаптації у колективі та до існуючої корпоративної політики організації;

- кваліфікація;

- надійність.

Перші два пункти знаходяться у віданні відділу персоналу та визначаються ним 3 допомогою традиційних психологічних методик та іншими засобами (співбесіда, збір та оцінка інформації о кандидатах, психологічні тестові процедури). Ризики, пов'язані з цими пунктами, в більший мірі залежать від кваліфікації самих співробітників служби персоналу, здійснюючих відбір, та кадрової корпоративної політики організації [5].

Визнанням надійності кандидата займаються спеціалізовані організації, наприклад, Центр детекції брехні. Частіш за все питанню надійності кандидата керівники організації, як показує практика, присвя- чують мало уваги. Дослідженнями, проведеними у 2002 році компанією "The Risk Advisory Group”, яка займається кадровою безпекою, встановлено наступне: у $70 \%$ випадків при наймі на роботу кандидати вказували недостовірні відомості, приховували чи навмисно перекручували факти попередніх звільнень та посади, які вони займали. Американська асоціація професійних слідчих по справам о шахрайстві у 2000 році заявила, що власники третини збанкрутілих компаній визнали, що причиною їх розорення стали розкрадання власного персоналу. Ось чому проблема якісного підбору персоналу така важлива, а вирішувати іiі на сьогодні треба 3 використанням сучасних методів та засобів [4].

В деяких організаціях проблема підбору надійного нового співробітника вирішується за допомогою оцінки запропонованих рекомендацій та випробувального терміну. До них іноді добавляють традиційні кадрові перевірки, суть яких складається у надмірному вивченні біографічного та трудового минулого кандидата для прогнозу його благонадійності в майбутньому. Такі перевірки здійснюються, як правило, уповноваженими співробітниками організації (найчастіше це фахівці служби безпеки). Але навіть у таких компаніях прийняття рішень про надійність кандидата часто спрощується до визнання дійсності наданих документів, правдивості наданої їм персональної інформації, наявності в нього судимос- 
тей, фактів нанесення шкоди на попередньому місці роботи. Всього цього не достатньо. Такі кадрові перевірки, засновані на зборі інформації про кандидата, іноді затягуються до декількох місяців, а то і більше. Вирішення кадрових проблем потребує нових підходів. Наприклад, застосування поліграфа, що дозволяє скоротити кадрову перевірку до двох-трьох годин та отримати інформацію від кандидата, яку іншим засобом получити не можливо. Тут мова йде про використання в організації співробітника, який потім буде працювати на ініціатора впровадження (кримінал, конкурентів), або про факти у біографії кандидата, які залишилися невідомі: кримінальні злочини, адміністративні чи посадові зловживання, пагубні пристрасті та ін. Ступень достовірності отриманої інформації з допомогою поліграфа, як правило, більше 90\%. Наступний напрям в рішенні кадрових проблем - профілактика, до якої входять заходи, методи та принципи, які спрямовані на встановлення позитивних відносин між працедавцем та робітником для підвищення ступеню лояльності останнього. Створення та впровадження корпоративних систем колективної та персональної мотивації, матеріального стимулювання, навчання всередині фірми, підвищення кваліфікації та перепідготовки, програми кар'єрного зросту - ось деякі із заходів, які дозволяють підтримувати ці відносини на повинному рівні [2].

У профілактику звичайно укладають недостатню кількість коштів. Така економія призводить до того, що організація вимушена витрачати більше ресурсів на заходи третьої направленості - здійснення контролю [6].

Контроль - це комплекс заходів, які направлені на увесь персонал компанії, який складається 3 регламентів, інструкцій, обов'язків, обмежень, режимів, технологічних процесів, оцінок, контрольних та iн. операцій та процедур безпеки. Він орієнтований на ліквідацію можливостей спричинення шкоди персоналом та проведення всередині фірми службових розглядів по фактам, які вже трапилися [11].

Щоб створити систему управління персоналом банку, треба чітко визначити концепцію, принципи, політику та стратегію управління персоналом.

Концепція управління персоналом - це комплекс теоретико-методологічних поглядів на розуміння суті, змісту, цілей, завдань, принципів, критеріїв та організаційно-практичних методів управління персоналом, а також підходів до формування механізму їх реалізації в конкретних умовах функціонування управлінь, відділень і філій.

Існують певні вимоги для розробки і реалізації концепції управління персоналом:

- для практичного використання концепція управління персоналом повинна бути чітко сформульована у вигляді сукупності нормативних положень;

- для узаконення положень концепції вона повинна бути зафіксована у певному організаційнорозпорядчому документі;

- концепція управління персоналом повинна діяти протягом певного періоду, достатнього для іiі реалізації, а у зв'язку з динамікою зовнішнього і внутрішнього середовища - періодично переглядатися і уточнюватися.

Формулювання концепції управління персоналом здійснюється поетапно і охоплює 7 кроків (Рис. 2).

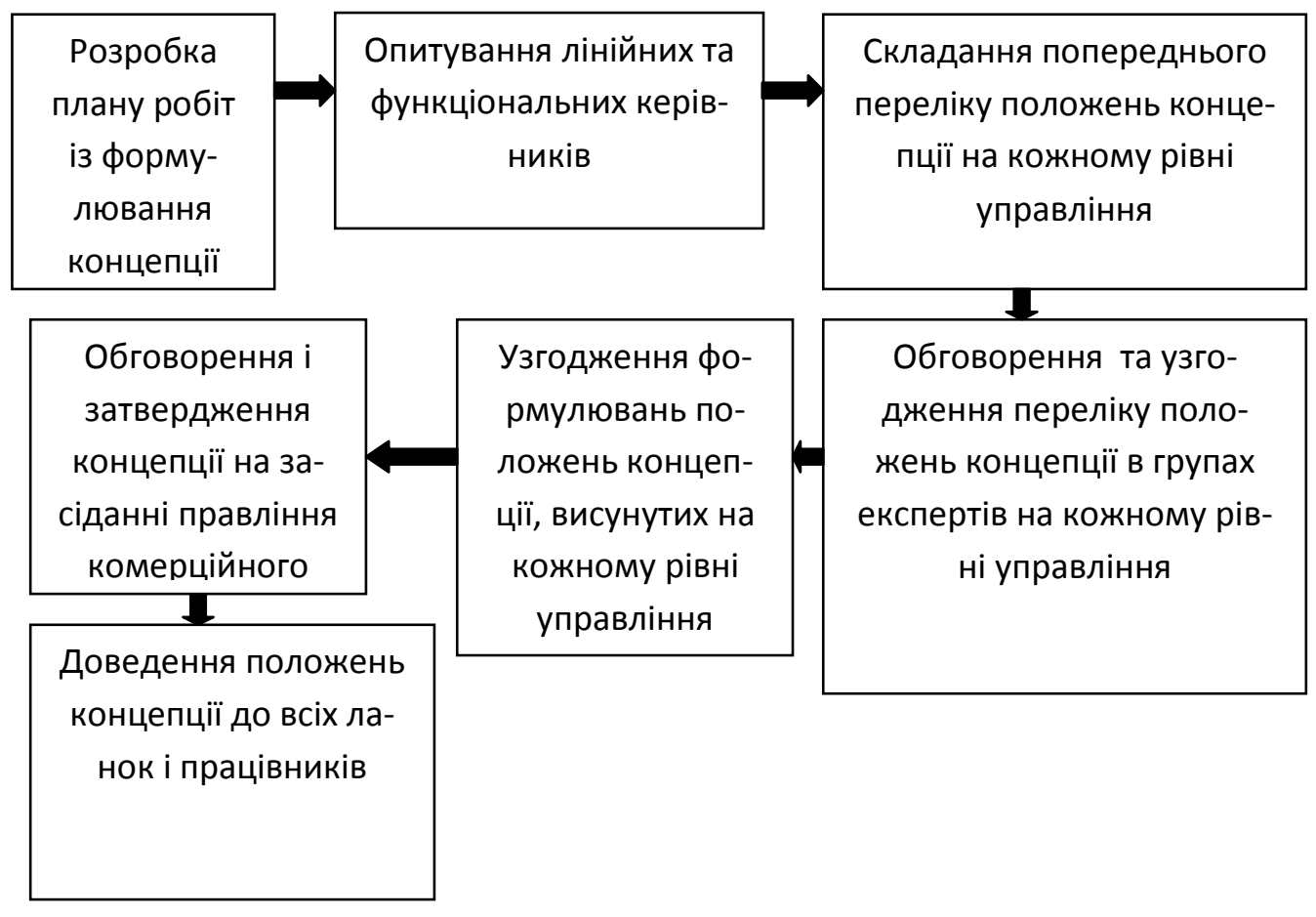

Рис. 2. Процес розробки концепції управління персоналом у системі комерційного банку

Формування концепції розпочинається 3 поетапного експертного опитування лінійних керівників та працівників функціональних кадрових служб системи Одержані пропозиції обговорюються на групо- 
вих нарадах експертів, починаючи 3 філій банку. Узгоджені формулювання подаються інстанціям і таким чином розробляється проект концепції, який виноситься на розгляд і затвердження правління банку [18].

Розроблена концепція є підставою для формулювання системи принципів управління персоналом.

Під принципами управління персоналом розуміється певна сукупність правил і норм, прийнятих в організації, якими керуються лінійні та функціональні керівники в процесі вирішення кадрових питань. Правила і норми поведінки стають принципами, якщо вони загальновизнані і зафіксовані у певних нормативно-правових документах, обов'язкових для виконання всіма ланками системи (організації).

До складу основних принципів управління персоналом в системі банку входять: науковість, об'єктивність, демократизм, гласність, підбір кадрів за діловими і моральними якостями; ротація кадрів; поєднання інтересів системи, колективу і особистості; пропорційність; балансування вікового чинника; поєднання вимогливості і контролю роботи працівників з повагою до них.

Концепція та принципи управління персоналом є відправними моментами для розробки політики управління персоналом (кадрової політики).

Під кадровою політикою розуміються основні напрями, форми, методи та критерії роботи 3 персоналом, спрямовані на підвищення ефективності його використання і діяльності системи банку в цілому [16, 17]. Політика не вимагає безпосередніх дій, однак вона формується для того, щоб лінійні і функціональні керівники керувалися нею, аналізували можливі наслідки рішень 3 кадрових питань до того, як ці рішення прийняті.

Основними складовими кадрової політики є:

- $\quad$ політика набору, відбору і розстановки кадрів;

- політика профорієнтації, адаптації і підвищення кваліфікації;

- $\quad$ політика зайнятості;

- політика управління службовим зрос-

танням;

- $\quad$ політика стимулювання;

- с соціальна політика.

Політика $\epsilon$ основою розробки стратегії управління персоналом. Нині поняття стратегія широко використовується в управлінській практиці як сукупність довготермінових заходів з управління надійністю ресурсів, до числа яких належать і кадрові ресурси (кадровий потенціал). При розробці стратегії діяльності організації важливим є питання визначення оптимальної тривалості стратегічного періоду [13].

Очевидно, що стратегічним є такий період часу, протягом якого в діяльності організації (підприємства) відбуваються суттєві якісні і (або) кількісні зміни. На думку більшості економістів, стратегічний період повинен охоплювати понад 10 років. Однак тривалість періоду, протягом якого відбуваються стратегічні зміни, залежить від багатьох чинників: сфери діяльності організації (підприємства), динаміки чинників зовнішнього середовища, виду задіяних ресурсів. Мінімальний період, протягом якого відбуваються відчутні стратегічні зміни персоналу організації, становить в середньому близько п'яти років. Тому стратегія управління надійністю персоналу комерційного банку повинна розроблятися на кожні п'ять років.

Під стратегією управління надійністю персоналу розуміється комплекс основних складових елементів, які повинні стати вузловими при побудові системи управління персоналом.

Розробка стратегії управління персоналом це продуманий, повністю усвідомлений і контрольований розумовий процес, який передбачає, що за визначенням стратегії наступить іiі реалізація. Мистецтво розробки стратегії управління персоналом полягає в тому, щоб наслідками формулювання загальних підходів до управління персоналом у стратегічному періоді стали конкретні дії, які б дозволили досягти високої ефективності використання трудового потенціалу персоналу. Стратегія управління персоналом $\epsilon$ складовою частиною загальної стратегії діяльності комерційного банку, а сама ця стратегія випливає зі стратегії розвитку господарської діяльності - стратегії управління його активами і пасивами, стратегії залучення коштів, стратегії кредитування та інвестицій. У принципі, банк, як і будь-яка інша комерційна організація, може обрати одну з п'яти стратегій: стратегію підприємництва, стратегію динамічного зростання, стратегію прибутку, стратегію ліквідності, стратегію зміни курсу. Вибір тієї чи іншої стратегії впливає на стратегію управління персоналом.

Більшість комерційних банків України обирають стратегію динамічного зростання. Розробка стратегії надійності управління персоналом, яка випливає зі стратегії динамічного зростання, передбачає поетапне визначення мети, критеріїв і показників ефективності, обмежень на функціонування системи управління персоналом (фінансових, матеріальних, соціальних), організаційної структури служб управління персоналом, взаємозв'язків системи банку із зовнішнім середовищем [3].

Стратегія управління персоналом повинна враховувати певні обмеження на функціонування системи управління персоналом. До числа їх належать фінансові, матеріальні, соціальні обмеження.

Фінансові обмеження визначаються лімітом коштів, які виділяються в кошторисі витрат на утримання персоналу. Оскільки кошти на утримання персоналу можуть спрямовуватися на різні цілі (підвищення заробітної плати всіх працівників чи окремих категорій, розширення штатів при збереженні наявного рівня оплати праці, купівля засобів оргтехніки тощо), то зрозуміло, що фінансові обмеження є однією $з$ основ розробки стратегії управління персоналом.

Матеріальні обмеження стосуються наявної інфраструктури установ банку (приміщень, засобів механізації управлінської праці та ін.).

Соціальні обмеження $є$ результатом загальних тенденцій розвитку ринку праці в країні і в регіонах, соціальної політики держави, вимог профспілко- 
вих організацій банківських працівників до працедавців тощо.

Формування стратегії управління персоналом знаходиться під впливом взаємозв'язків системи банку із зовнішнім середовищем. У зовнішньому середовищі можна виділити три системи: економіку, суспільство, екосистему. Економіка - це частина суспільства, діяльність якої спрямована на скорочення дефіцитів шляхом створення робочих місць, виготовлення і розподілу товарів та послуг.

Для аналізу зв'язків між системою банку і іï зовнішнім середовищем важливе значення має так звана концепція групових претензій. Ця концепція виходить 3 того, що різноманітні підприємства, заклади, установи знаходяться в постійній конфронтації 3 різними групами інтересів, зміст яких впливає на їх майбутне становище.

Специфіка взаємовідносин системи комерційного банку із зовнішнім середовищем полягає в тому, що його установи не можуть контролювати поведінку зацікавлених груп.

Установи банку, як правило, мають справу 3 чотирма групами інтересів: співробітники);

- внутрішніми (акціонери, менеджери,

- господарськими (клієнти, кредитори, позичальники, конкуренти, потенційна робоча сила);

- $\quad$ громадськими (держава, засоби масової інформації, громадські організації тощо);

середовища (учені, асоціації зацікавлених організацій і груп, держава та ін.) [10].

Значення груп інтересів для кожної установи банку і для системи в цілому різне і визначається ситуаційно. Взаємини з ними постійно змінюються залежно від характеру взаємних претензій. Так, не тільки система банку та його установи мають певні обов'язки перед суспільством, але й суспільство як одна 3 груп претензій бере на себе певні зобов'язання перед ними. У результаті виникає необхідність організації цілеспрямованого стратегічного і оперативного управління зв'язками з розглянутими вище групами інтересів [12].

Висновки та перспективи подальших досліджень. Таким чином, людський чинник та кадровий корпоративний капітал - головний ресурс під- приємства, якщо ним кваліфіковано управляти, то він майже невичерпний. Успіх організації залежить від якості і надійності людських ресурсів і вміння ними управляти. Щоб створити систему управління персоналом банку треба чітко визначити концепцію, принципи, політику та стратегію управління персоналом. Добре зважена система по забезпеченню кадрової безпеки сучасного банку, складовими якої $\epsilon$ найм, профілактика та контроль, може вагомо зменшити збитки від невиробничих витрат, пов'язаних з персоналом. Для створення надійної та ефективної системи управління персоналом треба добре вивчити проблеми, пов'язані з формуванням служби персоналу, методи мотивації персоналу, планування оптимальної чисельності підрозділів банку.

Кожен банк повинен створювати власну службу персоналу, адаптовану до специфіки конкретного банку. Щоб зупинити плинність кадрів і не тільки зберегти найкращих співробітників, але і підвищити надійність та ефективність, банк повинен зробити наступне:

- дізнатися, чого насправді більш за все хочуть співробітники (за допомогою спілкування 3 ними і постійного зворотного зв'язку);

- представити широкий спектр можливостей росту та розвитку для співробітників будь-якого рівня;

- впроваджувати системи критеріїв і заохочень, які чітко виражають, чого саме банк очікує від співробітників і, відповідно, за що їх винагороджує.

Оптимально забезпечити планову потребу в кадрах кожної категорії можна шляхом переміщення всередині установи банку або найму. Рух персоналу між категоріями може вимагати їхньої перепідготовки. Вона необхідна також для того, щоб попередити старіння кадрів у межах категорій працівників

Вдосконалення процесу управління можливо за допомогою підвищення кваліфікації співробітників та вдосконалення системи оцінки персоналу.

Навчання персоналу сприяє, 3 одного боку, підвищенню ефективності діяльності банку та професійному росту співробітників, з іншого боку, - авторитету в очах партнерів та клієнтів, подальшому розвитку всієї галузі. Але навчання неможливе без правильно організованої оцінки персоналу.

\section{Література}

1. Закон України «Про зайнятість населення» від 5 липня 2012 року № 5067-VI. [Електронний ресурс] - Режим доступу : http: //zakon4.rada.gov.ua/laws/ show/5067-17.

2. Богданова Е. Л. Маркетинговая концепция организациии персонала - менеджмента и конкурентоспособной рабочей силы / Е. Л. Богданова // - СПб., 1997. - 352 с.

3. Власова А. Розвиток менеджменту: діагностика потреб у навчанні / А. Власова // HRD/Отдел кадров. - 2002. - № 01(64). - С. 34-35.

4. Воронина О. Оценка как составляющая системы развития персонала / О. Воронина, М. Первушина // HRD/Отдел кадров. - 2004. - № 23(134). - С.14-17.

5. Воронина О. Типичные ошибки в стимулировании персонала / О. Воронина // HRD/Отдел кадров. 2005. - № 10(145). - C.70-72.

6. Дуракова И. Б. Управление персоналом: отбор и наем. Исследование зарубежного опыта / И. Б. Дуракова // Воронеж : Изд-во Воронежского гос. ун-та, 1998. - 318 с. 
7. Свтушевська О. О. Методи управління трудовими ресурсами: японський досвід та особливості його трансформації в Україні / О. О. Свтушевська, В. А. Голубєв // Економіка харчової промисловості. - 2012. - № 3(15). - С. 26-30.

8. Журавлёв П. В. Персонал. Словарь понятий и определений / П. В. Журавлёв, С. А. Карташов, Н. К. Маусов, Ю. Г. Одегов // М. : Экзамен, 1999. - 517 с.

9. Маслов Б. От управления кадрами - к управлению персоналом / Б. Маслов // HRD/Отдел кадров. 2002. - № 4(67) . - С. 6-7.

10. Мороз Е. Методы оценки персонала / Е. Мороз // HRD/Отдел кадров. - 2005. - № 7(142). - С. 62-65.

11. Одегов Ю. Г. Управление персоналом банка / Ю. Г. Одегов, Т. В. Никонова, Д. А. Безделов // М. : РЭА им. Г.В. Плеханова, 1999. - 306 с.

12. Синчалова И. Методы эффективной оценки персонала / И. Синчалова // HRD/Отдел кадров. - 2002. - № 21(84). - C. 6-7.

13. Соловьёв В. Індикатор зрелости, или риски учебных центров / В. Соловьёв // Обучение персонала. 2006. - № 1. - С. 18-22.

14. Тарасова О. В. Корпоративна культура як інструмент ефективного менеджменту підприємства / О. В.Тарасова, С. С. Марінова // Економіка харчової промисловості, № 3(19), 2013. - С. $28-33$.

15. Тарасова О. В. Стан і тенденції розвитку банківської системи України / О. В. Тарасова, Ю. О. Панова // Економіка харчової промисловості, № 3(23), 2014. - С. 79-86.

C. 7 .

16. Торшина К. Карьера и мотивация / К. Торшина, Ю. Пасс // HRD/Отдел кадров. - 2002. - № 19(82). -

17. Травин В. В. Менеджмент персонала предприятия / В. В. Травин, В. А. Дятлов // М. : Дело, 2003. $412 \mathrm{c}$.

18. Экономика труда и социально-трудовые отношения / Под ред. Р.П. Колосовой // М. : Аспект Пресс, 1998. - 292 c.

Стаття надійшла 10.02.2015

\author{
Евтушевская О.А. \\ кандидат экономических наук, доцент \\ кафедра учета и аудита \\ Одесская национальная академия пищевых технологий \\ ул. Канатная, 112, г. Одесса, Украина, 65039 \\ E-mail: olga1alex@mail.ru
}

\title{
СОВЕРШЕНСТВОВАНИЕ СИСТЕМЫ ОБЕСПЕЧЕНИЯ НАДЕЖНОСТИ ПЕРСОНАЛА КОММЕРЧЕСКОГО БАНКА
}

\footnotetext{
Основной целью статьи является разработка теоретических и практических рекомендаций по совершенствованию надежности персонала коммерческого банка. Для создания эффективной системы управления персоналом банка нужно четко определить концепцию, принципы, политику и стратегию управления персоналом.

Концепция управления персоналом - это комплекс теоретико-методологических взглядов на понимание сущности, содержания, целей, задач, принципов, критериев и организационно-практических методов управления персоналом, а также подходов к формированию механизма их реализации в конкретных условиях фрункционирования управлений, отделений и филиалов. Разработанная концепция является основанием для формулирования системы принципов управления персоналом. В состав основных принципов управления персоналом в системе банка входят: научность, объективность, демократизм, гласность, подбор кадров по деловым и моральным качествам; ротация кадров; сочетание интересов системы, коллектива и личности; пропорциональность; балансировка возрастного фрактора; сочетание требовательности и контроля работы сотрудников с уважением к ним.

Концепция и принципы управления персоналом являются отправными моментами для разработки политики управления персоналом (кадровой политики). Политика является основой разработки стратегии управления персоналом. Человеческий фактор и кадровый корпоративный капитал - главный ресурс компании, если им квалифицированно управлять, то он почти неисчерпаем. Успех организации зависит от качества и надежности человеческих ресурсов и умения ими управлять.

Ключевые слова: концепция управления персоналом, принципы управления персоналом, политика управления персоналом, стратегия управления персоналом.
} 
Yevtushevska O.A.

Ph.D. in Economics, Associate Professor

Department of Accounting and Auditing

Odessa National Academy of Food Technologies

Kanatnaya Str., 112, Odessa, Ukraine, 65039

E-mail: olga1alex@mail.ru

\section{IMPROVING THE SYSTEM OF ENSURING THE RELIABILITY OF COMMERCIAL BANK STAFF}

The main objective of this article is to develop a theoretical and practical recommendations to improve the reliability of the staff of a commercial Bank. To create an effective system of personnel management of the Bank, it is necessary to clearly define the vision, principles, policy and strategy of personnel management.

The concept of personnel management is a complex theoretical and methodological perspectives on the understanding of the nature, content, goals, objectives, principles, criteria and practical methods of personnel management, and approaches to the formation of the mechanism of their implementation in specific conditions of operation of departments, divisions and branches. The developed concept is the basis for the formulation of a system of personnel administration. In the composition of the basic principles of personnel management system of the Bank consists of: science, objectivity, democracy, openness, recruitment business and moral qualities; rotation; the combination of the interests of the system, the collective and the individual; proportionality; balancing the age factor; the combination of rigor and control the work of employees with respect thereto. The concept and principles of personnel management are the starting points for policy development of personnel management (personnel policy). Policy is the basis of the development strategy of personnel management. The human factor and human resources corporate capital is the main resource of the enterprise, if they are qualified to manage, it is almost inexhaustible. The success of the organization depends on the quality and reliability of human resources and the ability to manage them.

Keywords: concept of personnel management, personnel administration, personnel management policy, strategy management staff.

\section{References}

1. Zakon Ukrainy «Pro zainiatist naselennia» vid 5 lypnia 2012 roku № 5067-VI. [Elektronnyi resurs]. Rezhym dostupu : http: //zakon4.rada.gov.ua/laws/ show/5067-17.

2. Bohdanova E. L. (1997). Marketynhovaia kontseptsyia orhanyzatsyyy personala-menedzhmenta y konkurentosposobnoi rabochei syly. SPb., 352.

3. Vlasova A. (2002). Rozvytok menedzhmentu: diahnostyka potreb u navchanni. HRD/Otdel kadrov. № 01(64), 34-35.

4. Voronyna O. (2004). Otsenka kak sostavliaiushchaia systemy razvytyia personala. O. Voronyna, M. Pervushyna. HRD/Otdel kadrov. № 23(134), 14-17.

5. Voronyna O. (2005). Typychnye oshybky v stymulyrovanyy personala. HRD/Otdel kadrov, № 10(145), 70-72.

6. Durakova Y. B. (1998). Upravlenye personalom: otbor y naem. Yssledovanye zarubezhnoho opyta. Voronezh : Yzd-vo Voronezhskoho hos. un-ta, 318.

7. Yevtushevska O. O. (2012). Metody upravlinnia trudovymy resursamy: yaponskyi dosvid ta osoblyvosti yoho transformatsii v Ukraini. O. O. Yevtushevska, V. A. Holubiev. Ekonomika kharchovoi promyslovosti, № 3(15), 26-30.

8. Zhuravlëv P. V. (1999). Personal. Slovar poniatyi y opredelenyi. P. V. Zhuravlëv, S. A. Kartashov, N. K. Mausov, Yu. H. Odehov. M. : Эkzamen, 517.

9. Maslov B. (2002). Ot upravlenyia kadramy - k upravlenyiu personalom. HRD/Otdel kadrov, № 4(67), 6-7.

10. Moroz E. (2005). Metody otsenky personala. HRD/Otdel kadrov. № 7(142), 62-65.

11. Odehov Yu. H. (1999). Upravlenye personalom banka / Yu. H. Odehov, T. V. Nykonova, D. A. Bezdelov. M. : REA ym. H.V. Plekhanova, 306.

12. Synchalova Y. (2002). Metody effektyvnoi otsenky personala. HRD/Otdel kadrov. № 21(84), 6-7.

13. Solovëv V. (2006). Indykator zrelosty, yly rysky uchebnykh tsentrov. Obuchenye personala. № 1, 18-22.

14. Tarasova O. V. (2013). Korporatyvna kultura yak instrument efektyvnoho menedzhmentu pidpryiemstva. O. V. Tarasova, S. S. Marinova. Ekonomika kharchovoi promyslovosti, № 3(19), 28-33.

15. Tarasova O. V. (2014). Stan i tendentsii rozvytku bankivskoi systemy Ukrainy O. V. Tarasova, Yu. O. Panova. Ekonomika kharchovoi promyslovosti, № 3(23), 79-86.

16. Torshyna K. (2002). Karera y motyvatsyia. K. Torshyna, Yu. Pass. HRD/Otdel kadrov. № 19(82), 7.

17. Travyn V. V. (2003). Menedzhment personala predpryiatyia. V. V. Travyn, V. A. Diatlov. M. : Delo, 412.

18. Ekonomyka truda y sotsyalno-trudovye otnoshenyia. (1998). Pod red. R. P. Kolosovoi. M. : Aspekt Press,

292. 